\title{
DRAMATIS PERSONAE
}

The Alloway family of Bridgwater in Somerset were merchants and mariners, trading in both European and American waters in the late seventeenth and early eighteenth centuries. Their involvement in the herring fishery of England's south-west and the cod fishery of Newfoundland led to their investing in the manufacture of salt, that essential preserving agent. Graffin Prankard (q.v.) married into the family in 1708 - they were Quakers, like him - and followed them into the salt business. Nathaniel Alloway, Prankard's cousin, was master of the Baltick Merchant.

Reinhold Rütker ANgersteiv (1718-1760), an ironmaster's son, was appointed to the Bergscollegium in 1738. Between 1752 and 1758 he was engaged in a more or less continuous tour of Europe, visiting the German lands, Hungary, Italy, Spain, France, Britain and the Netherlands. At the time of his death Angerstein held the post of Assessor; only the Bergscollegium's president and his two counsellors outranked him.

John Bannister (d. 1743) had day-to-day management of the Crowley family firm after the death of John Crowley in 1728 and was a partner of Crowley Hallett's (q.v.) in the firm Harrison, Bannister \& Hallett. His appearance before the 1737 committee of the House of Commons on the iron trade featured a tendentious warning against the dangers of hardware manufacturing being tolerated in the North American colonies.

Anders BERGH (1711-1774), professor of economics at Uppsala University from 1741, wrote the first economics text-book in Swedish, Inledning til almänna hushålningen, innefattande grunden til politie, oeconomie och cameral wetenskaperne [An introduction to common householding, including the foundations of political, economical and cameral science] (1747).

Christer Berch (1733-1792), the son of Anders Berch and his successor as professor of economics at Uppsala. Berch's 'grand tour' in 1757-1761, included a spell in Britain. 
Willem de Besche (1573-1629), Dutch entrepreneur, was Louis De Geer's chief associate in opening up Sweden's iron and copper industries to foreign investment in the 1620s. Like his compatriot, De Besche owned or rented ironworks in Uppland and several other counties.

Johan (or Jean) Bolinder (1813-1899), engineer and businessman. Bolinder was recruited to Fernkontoret in 1838 and sent on a mission to Britain in 1842-43. He was instrumental in transplanting British production techniques to Sweden, where he established in his own engineering firm in 1850.

Carl Bonde (1581-1652), Swedish nobleman and servant to the Crown, was one of the founding fathers of the Bergscollegium.

Auguste-Henri de BonNaRd (1781-1857), mining engineer and geologist, graduated from the Ecole des Mines de Paris in 1801 and undertook a tour of British coalfields during the brief period of peace that followed the Treaty of Amiens in 1802. After his return to France he enjoyed a distinguished career as secretary to the Conseil général des Mines.

The Botfield family were important practitioners of coal-based technologies in the Shropshire iron industry. Thomas Botfield (1738-1801) became a partner in Lightmoor furnace in 1758, just as coke smelting became standard practice on the east Shropshire coalfield. He founded a new works at Old Park in 1790 that was soon equipped with a steamdriven rolling mill.

Gustaf Broling (1766-1838), Bergscollegium agent, visited Britain in 1797-99. His well-received travel account included a full description of crucible steel making in Sheffield. Broling established his own crucible plant in 1808.

Robert Campbell (d. 1758) came to Stockholm from Scotland in the first decade of the eighteenth century. By the 1720s he was one of the city's leading exporters of bar iron.

The Carroll family of Annapolis, Maryland, were among the largest planters and merchants in the Chesapeake. Charles Carroll (1691-1755) was the principal investor in the Baltimore Company, established in 1731, which was to be one of the largest iron-making concerns in 
the mid-Atlantic region and one of those most focused on the British market.

Henry CoRT (1741-1800) patented the puddling and rolling method in the mid-1780s, but he derived little personal benefit from the technological breakthrough he did so much to bring about. He was unwittingly caught up in the malfeasance of his business partners and bankrupted in 1789. His patents were forfeit to the state, but the government made little effort to collect the royalties due. As a result, British ironmasters were able to exploit Cort's methods for free.

Thomas Coster (1684-1739), MP for Bristol from 1734 until his death, was a member of an eminent industrial dynasty, one responsible for the rise of a coal-fired copper smelting industry in the Forest of Dean (from the 1690s), then in the Neath and Swansea valleys of south Wales (from the 1720s). Related investments in brass manufacture tied the family's fortunes very firmly to the slave-based commerce of the city Thomas Coster represented in Parliament. Indeed, he was part-owner of the Amoretta, which shipped slaves to Carolina through the 1730s.

Richard Crawshay (1739-1810) began his career in the 1760s as a dealer in iron hollow wares in London. Soon, he moved into the Baltic trade, importing iron and timber from Sweden. By the 1780s he was probably the capital's foremost iron merchant. Not content with that, he re-launched himself as an ironmaster, taking over the Cyfarthfa works in Wales. Within a decade the works were Britain's largest, where the latest in coal technology was showcased.

The Crowley family was established as a force in the British iron trade by Ambrose Crowley (1658-1713), the son of a Stourbridge ironmonger of the same name. A man of granite authority, Ambrose Crowley established himself as an ironmonger in London in the 1680s and, having fallen out with his suppliers, began to manufacture iron wares on his own account, establishing factories in the North East of England for that purpose. Although born a Quaker, Ambrose Crowley became an Anglican and an ardent Tory. His son and successor, John Crowley (1689-1728), was a Jacobite - a risky allegiance for someone whose business depended on naval contracts from the Hanoverian regime. After John's early death the sprawling Crowley empire was headed by his widow Theodosia (1694-1782). 
Abraham Darby (1678-1717), a native of the nail country around Dudley, set up business in Bristol as a brass manufacturer and iron founder at the turn of the eighteenth century. Soon after, he shifted his attention to Shropshire, where he was involved in establishing a brass battery, rolling mill, wire mill and steel furnace near Shrewsbury and taking over the blast furnace at Coalbrookdale. Graffin Prankard was an investor in both projects, albeit fleetingly. Darby was an important innovator in brass making, but it was in ferrous metallurgy that he made his most enduring contribution, using coke to smelt iron at Coalbrookdale.

The De Geer family was of Walloon origin but Louis De Geer (1587-1652), the founder of the family's fortunes, first made his mark in Amsterdam where he flourished as a merchant. In the 1620s he moved again, this time to Sweden, where he established himself as the country's leading merchant, mine owner and industrialist. The Uppland bruk at Leufsta, Österby and Gimo, and the cannon foundry at Finspång, south of Stockholm, were his principal bases. In the early eighteenth century the family concerns were dominated by two of Louis De Geer's grandsons, the brothers CARL De Geer (1660-1730) and Jean Jagques De Geer (1666-1738). They consolidated and extended the De Geer domains in the county of Uppland, taking additional shares in the Dannemora mine and acquiring new ironworks. Carl De Geer died childless, but Jean Jacques had three sons - Louis De Geer (1705-1758), Charles De Geer (1720-1778) and Antoine De Geer (1721-1756) - under whose guidance the family continued to dominate iron making in Uppland and in Sweden as a whole.

The Demidov family dominated Russian iron making in the eighteenth century. The family's fortunes were founded by Nikita Demidovich Antufyev (1656-1725), a blacksmith from the metalworking city of Tula in western Russia who was one of Peter the Great's metallurgical pioneers on the Siberian frontier. His son, Akinfy Nikitich Demidov (1678-1745), added to his father's industrial empire, so that he controlled 25 ironworks and copper works at the time of his death. The sable mark that was imprinted on the family's iron was an internationally recognised brand.

Caleb Dickinson (1716-1783), Bristol merchant and landowner. Dickinson was apprenticed to his co-religionist Graffin Prankard 
and married his master's daughter on the completion of his term in 1738. He also inherited estates in Somerset and a share in a sugar plantation in Jamaica, yielding a wealth that allowed him to save his father-in-law from bankruptcy during the crisis of Prankard's affairs in $1739-1740$.

William Donne, the Bristol ironmonger, claimed to have 'two furnaces in Virginia \& two slitting mills in Eng[lan]d' when he gave evidence to a committee of the House of Commons in 1737. One of the slitting mills was that at Congresbury in Somerset where he processed Russian iron bought from Graffin Prankard. He was also a partner in the 'Bristol' ironworks in Virginia, which supplied pig iron to the forges of the Knight family (q.v.). The second colonial furnace has not been identified.

Gustaf Eкмал (1804-1876), the son of a Gothenberg merchant, joined fernkontoret in 1827 after graduating from Uppsala. His first-hand observation of British forge techniques, made on three separate trips between 1828 and 1833, led him to devise the Lancashire forging method.

The gun-maker Joseph FARMER (d. 1741) described himself as 'a manufacturer of steel wares at Birmingham' when he appeared before the House of Commons committee on the iron trade in 1737 as an advocate of importing American bar iron. Farmer had visited the plantations in 1718-1719 and become convinced of their potential as iron making territories. He acted on his conviction, helping to establish the Principio Company in Maryland in the 1720s.

James FARMER (1715-1773) took over the gun-making business of his father Joseph (q.v.) in the 1740s. In partnership with his brother-in-law Samuel Galton, he was one of Birmingham's leading manufacturers.

Jacob FeIfF (1679-1736), a Stockholm merchant born into a family of Scottish origin, handled the export of iron from a variety of bruk, including Gammelbo. He was also an ironmaster in his own right, renting Wattholma bruk, for example, in the early 1730s.

The Finch family of Dudley were major putting-out employers in the West Midlands nail trade. They also maintained a London warehouse. 
Edward Finch (c. 1697-1771) was a younger son of the Earl of Nottingham. He was MP for Cambridge from 1727 to 1768, but for most of his early career he served as a diplomat in the Baltic. He was envoy to the Polish court from 1725 to 1727 , to the Swedish court from 1728 to 1739 , and to the Russian court from 1740 to 1742 .

The Freeths were prominent as Birmingham tool makers over several generations. Sampson Freeth features regularly in Graffin Prankard's accounts from the 1730s, buying between four and seven tons of iron annually.

John Galton (1671-1743), like Graffin Prankard, his fellow Bristol merchant, married into the Alloway family (q.v.). His son Samuel (1720-1799) moved to Birmingham to set in partnership with his kinsman James Farmer (q.v.), the gun manufacturer.

The GRILL family were merchants of Dutch descent, active in both Amsterdam and Stockholm. The firm headed by Carlos Grill (1681-1736) and his nephew ClaAes GRILL (1705-1767) was one of the leading iron export houses in the Swedish capital. They traded mainly with Amsterdam, where the sale of iron was handled by ANTHONY GRILL (1705-1783), the twin brother of Claes. The family also owned important ironworks, such as Söderfors, purchased in 1748, and Österby, acquired from Charles De Geer in 1758. Members of the family were also very active in the Swedish East India Company.

Fredrik GylleNBorg (1698-1759) was an important ironmaster and president of the Bergscollegium from 1750.

Crowley Hallett (1711-1767), grandson of Ambrose Crowley (q.v.), was a London ironmonger and sometime partner of Josias Wordsworth (q.v.).

William Hill (1741-1816), ironmaster and politician. Like many Scots-Irish of his generation, Belfast-born Hill found his way to the Carolina backcountry, where he had acquired more than 5,000 acres of land by the outbreak of the Revolution. The revolutionary war saw him engage in munitions production at his new-built Aera furnace and perform military service as an officer in the famous militia brigade of Thomas Sumter. As an activist in state politics after the war, William 
Hill was instrumental in promoting river navigation and canal schemes that would open up the backcountry.

Homfray family. Francis Homfray (1674-1737) served Ambrose Crowley (q.v.) as a nail warehouseman in the Stourbridge district in the 1690s. In 1702 he branched out on his own account and became an important figure in the West Midland nail trade in his own right. The business, which comprised forges and mills on the river Stour, continued to thrive after his death under the management of his wife Mary (d. 1758) and his son Francis (1725-1798). The third generation was instrumental in the coal technology revolution in South Wales in the 1780s and 1790s. Samuel Homfray (1762-1822) and his brother Jeremiah (1759-1833) established the Penydarren works at Merthyr Tydfil, one of the first to employ the puddling process.

Benjamin Huntsman (1704-1776), the inventor of crucible steel, began his working life as a clockmaker and continued in that trade into the 1740 s. By the 1750s, however, he had specialised as a steel refiner, whose distinctive product enjoyed a European celebrity.

The London Quaker, Thomas Hyam, was Graffin Prankard's banker. Bills of exchange drawn on Hyam were the means by which payment was made to Prankard's suppliers in Holland and the Baltic.

Gabriel Jars (1732-1769) was a star pupil at the Ecole des Ponts et Chaussées, the main centre of training for engineers in Enlightenment France. He was sent to investigate English technology in the wake of the Seven Years' War. His mission was wide-ranging, but his instructions directed him to pay particular attention to English steel making and to the manufacture of files, which were thought superior to those of any other European country.

Francis Jennings (1692-1754), an Ulsterman who naturalised as Frans fenning in Sweden, was Stockholm's most important iron exporter in the second quarter of the eighteenth century. Like many export merchants, Jennings acquired bruk of his own, in this case Forsmark, bought in 1751 .

Henric Kahlmeter (1693-1750), Bergscollegium agent, spent four years in Britain in the 1720s. 
Pehr KaLm (1716-1779), a naturalist who trained under Linnaeus at Uppsala, became the first professor of 'Oeconomia' at Åbo in his native Finland.

John Kettle of Birmingham was Graffin Prankard's single most important customer. His two cementation steel furnaces consumed a major part of the 'Orground' iron that Prankard imported.

The KNight family dominated the iron trade in the English Midlands in the middle decades of the eighteenth century. Richard Knight (1659-1745) and his sons ran a variety of furnaces and forges in the Severn and Stour valleys, with much of the output being marketed through their kinsman and partner Abraham Spooner (q.v.). Because the capacity of their forges regularly outran the supply of pig iron from their furnaces, the Knights were keen to experiment with American pig when it appeared on the British market in the 1730s.

Pierre-Guillaume-Frèdèric LE PLAY (1806-1882), engineer, metallurgist and social scientist, was trained at the Ecole des Mines in Paris. An inveterate traveller and investigator, Le Play was familiar with both the Ural ironworks of the Demidov family (q.v.) and the Vallonbruk of Uppland.

Sampson Lloyd (1699-1779) was the son of Quaker ironmonger in Birmingham. Ambrose Crowley (q.v.) was a maternal uncle. By the 1730s Lloyd had expanded his father's business by integrating backwards into iron slitting at the 'town mill' in Birmingham. He was also to invest in forges, such as that at Powick in Worcestershire. In later life Sampson Lloyd engaged in banking; his bank was the ancestor of the present-day Lloyds TSB Group.

Charles Marescoe (c. 1633-1670) was one of the most important Baltic merchants in Restoration London. He was a major importer of Swedish tar, iron and copper, and an exporter of colonial sugar and tobacco to Amsterdam and Hamburg. His brother-in-law and partner Peter Joye (1636-1721) continued in the Baltic trade into the eighteenth century, supplying iron to the East India Company in Queen Anne's reign.

Daniel Mather ran a manufactory at Toxteth Park, near Liverpool, where 'tongs, pliers, wires, small hammers and other tools for watch- 
makers, which he claims to be the best in England', were made. Mather published a catalogue of horological tools in 1775 .

Teofron Munktell (1805-1887), engineer and entrepreneur, toured England in 1835. The knowledge of British practice that he gained was put to use at his own engineering works at Eskilstuna.

Anders Nordencrantz (1697-1772), parliamentarian and writer on economic affairs. In his youth Nordencrantz travelled widely, spending eighteen months in London studying English political and economic conditions. On his return to Sweden he was elected to the Riksdag, where he served as a dedicated Hat (although he was later to switch to the Caps). In 1728 he was appointed Swedish consul in Lisbon, allowing him to refine his views on international commerce. Returning once more to Sweden, he became ironmaster and a key figure in establishing Jernkontoret in 1747.

Henry NorRis (fl. 1725-1736) was an eminent London Baltic merchant and a bitter rival of Graffin Prankard. In the early 1730s he was the most influential figure in the marketing of 'Orground' iron in Britain, which allowed him to discriminate against those who, like John Kettle, were associates of Prankard. It was, Prankard wailed, 'very hard on me to See ['Orground' iron] Pass by me here \& up into ye Markett \& Sold by a Person that wont Sell it on any reasonable terms or really not at all to my best Chapp [Kettle]' (letter to Francis Jennings, 16 August 1732).

Eric Odelstierna (1661-1704), metallurgist and Bergscollegium agent. Odelstierna made two lengthy tours of Europe. During the second, begun in 1690, he made the earliest Swedish observation of English steel making.

The English engineer Samuel Owen (1774-1854), who founded a mechanical workshop in Stockholm in 1809, played a crucial role in conveying technological novelties, such as rolling mills and steam engines, from Britain.

Axel Oxenstierna (1583-1654), Swedish statesman. As chancellor from 1612, Oxenstierna was the architect of stormaktstiden in both its political and economic aspects. 
The Pemberton family of Birmingham were prominent Quaker merchants who resided in the fashionable Square on the northside of the town. They dealt in hardware, like their kinsman and co-religionist Sampson Lloyd (q.v.). Another branch of the family was based in Philadelphia, playing a leading role in the commercial and political life of that city.

Tore Petré (1793-1853), parliamentarian and Gästrikland's leading ironmaster during the introduction of the 'New German Forging Method' to the county.

Christopher PolHem (1661-1751) was a self-taught engineer who came to fame after repairing the astronomical clock at Uppsala Cathedral. He was then employed at the Falu copper mine where he erected pumping and lifting gear. In 1700 Polhem founded Stjernsund bruk where both bar iron and metal wares were made with the aid of mechanical devices of his own design. The brukspatron of Stjernsund was a prolific writer who addressed the economic development of Sweden as well as scientific matters.

Graffin Prankard (d. 1756), Quaker merchant and industrialist, was active in the commerce of Bristol between the reign of Queen Anne and his insolvency in 1740. In addition to dealing in Baltic iron and timber, he sold cast iron wares from Coalbrookdale (where he was briefly a partner of Abraham Darby's) and salt produced at his own works in Worcestershire.

Bengt Andersson Qvist (1726-1799) was appointed to the Bergscollegium in 1755, and promoted to the senior post of Assessor in 1782. Qvist made an extensive grand tour in the second half of the 1760s. He used the observations he made in Britain to set up Sweden's first crucible steelworks on his return.

Sven Rinman (1720-1792) was the most renowned Swedish engineer and metallurgist of the later eighteenth century. An official of the Bergscollegium, he rose through its ranks to achieve the position of Bergsråd, the second highest office available, in 1782. Rinman was an able publicist, whose Bergwerks Lexicon (1788-89), an encyclopaedia of metallurgical knowledge, was his most notable work. He was the founder of a dynasty, for his son CarL RinMan (1763-1826) and grandson Ludvig Rinman (1815-1890) were also important figures in Swedish metallurgy. 
Samuel Schröder (1720-1779), who was ennobled as Schröderstierna in 1770, was an official of the Bergscollegium. He travelled widely through Holland, Britain, Germany, and France in 1748-1751. On his return home he was given oversight of bar iron manufacturing in Sweden.

The Shallard family owned the steel cementation furnace at Keynsham, near Bristol. John Shallard (d. 1735) operated the furnace in partnership with his son William, who outlived his father by just one year. On William's death in 1736 the business passed to his teenage son Christopher (1718-1754). Reinhold Angerstein (q.v.) visited the site shortly after Christopher Shallard's death; he found his widow 'so big and fat that she could have concealed the whole steel furnace'.

Samuel SHore (1676-1751), merchant and steel maker of Sheffield. A Dissenter of modest beginnings, Shore established two cementation furnaces in the Sheffield district in Queen Anne's reign. By the late 1720 s, when Shore was trading in partnership with his son Samuel (1707-1785), he felt sufficiently powerful to join with Graffin Prankard in an endeavour to monopolise the import of 'Orground' iron into the British Isles.

Abraham Spooner (1691-1788) was described as an 'Importer of Iron as well as Ironmonger' when he gave evidence before a committee of the House of Commons in 1737, who imported 'Orground' iron and several types of Russian iron. Graffin Prankard could testify to that, for Spooner was his deadly rival in the struggle to monopolise the supply of 'Orground' iron in the Midlands. The Birmingham ironmonger was supplied with Baltic iron via Henry Norris (q.v.).

Eric von Stockenström (1703-1790), ironmaster and Bergscollegium official, was one of the driving forces behind the establishment of Jernkontoret in the 1740s.

Peter Stubs (1756-1806) established a filesmith's business in his native Warrington in the 1770 s that became internationally renowned. The 'PS' mark stamped on his files was sought after not just in Britain but in America, where Sheffield-made counterfeits also circulated. 
Eric Thomas Svedenstienna (1765-1825), an official first of the Bergscollegium and then of Jernkontoret, made the grand tour that was customary for men in his position at the start of the nineteenth century. It fell to him to formulate a response to the crisis that struck Swedish iron making in the Napoleonic age.

Georg SwebiLius (d. 1735) was the general manager of Leufstawerken from 1722 until his death.

Adolf Gustaf Tамм (1805-1851) was appointed to Fernkontoret in 1827 and embarked on an investigative tour of Germany, France and Britain shortly afterwards. His findings were published as Anteckningar öfuer främmande länders jernhandtering, gjorde under en resa $i$ Tyskland, Frankrike och England, åren 1830 och 1831 (Stockholm, 1832).

Daniel TiLAs (1712-1772), polymath and parliamentarian, enjoyed a long and distinguished career with the Bergscollegium. He was ennobled in 1766 .

The firm of Tottie \& ARfwedson, founded by Carl Christopher Arfwedson (1735-1826) and his cousin Anders Tottie in 1771, dominated the export of bar iron from Stockholm in the last decades of the eighteenth century.

Eric Touscher succeeded Georg Swebilius (q.v.) as directeur at Leufstawarken in 1735.

Carl David af UhR (1770-1849), ironmaster and the author of an important work on charcoal making.

Olof W $\mathrm{IJK}$ (1786-1856), iron exporter and parliamentarian from Gothenberg.

Josias Wordsworth (d. 1749) was a London iron merchant and Baltic trader; he was also a considerable industrialist in the North East of England and a major exporter of hardware. He held the contract to supply bar iron to the Navy Board in 1733-36, 1740, 1742-43 and 1746. He also sold iron to the East India Company. 
Samuel Wordsworth, who was born about 1701, moved to Stockholm soon after the ending of the embargo that extinguished direct trade between Sweden and Britain in 1717-1719. In the 1730s he handled the export of 'Orground' iron to Samuel Shore (q.v.) of Sheffield, usually in association with Samuel Worster (q.v.), another British-born merchant.

Samuel Worster (d. 1746), a merchant of English origin, most likely from London, settled in Stockholm in the second decade of the eighteenth century.

John Wyke (1720-1787) was born near Prescot, Lancashire, where his father was a watch spring maker and where Wyke was to set up his own business as a watch maker and tool manufacturer. At the end of the 1750s Wyke moved to Liverpool where he became a prominent figure in the town's affairs. He supplied tools not only to the watch trade in his native region, but to more far flung industrial innovators and intellectuals like Josiah Wedgwood and James Watt.

Eric Adolf Zethelius (1781-1864), brukspatron at Nyby and Surahammar, was one of the earliest proponents of puddling in Sweden. 